Abstracta Iranica Abstracta Iranica

Revue bibliographique pour le domaine irano-aryen

Volume 29 | 2008

Comptes rendus des publications de 2006

\title{
"The Parthian Shot in Hunting Scenes ». Silk Road Art and Archaeology, 10, 2004, pp. 29-48.
}

\section{Carlo Lippolis}

\section{(2) OpenEdition}

1 Journals

\section{Édition électronique}

URL : http://journals.openedition.org/abstractairanica/27162

DOI : 10.4000/abstractairanica.27162

ISSN : 1961-960X

Éditeur :

CNRS (UMR 7528 Mondes iraniens et indiens), Éditions de l'IFRI

\section{Édition imprimée}

Date de publication : 15 mai 2008

ISSN : 0240-8910

\section{Référence électronique}

Carlo Lippolis, « «The Parthian Shot in Hunting Scenes ». Silk Road Art and Archaeology, 10, 2004, pp. 29-48. », Abstracta Iranica [En ligne], Volume 29 | 2008, document 133, mis en ligne le 15 septembre 2008, consulté le 26 septembre 2020. URL : http://journals.openedition.org/abstractairanica/27162 DOI : https://doi.org/10.4000/abstractairanica.27162

Ce document a été généré automatiquement le 26 septembre 2020.

Tous droits réservés 


\section{« The Parthian Shot in Hunting Scenes ». Silk Road Art and Archaeology, 10, 2004, pp. 29-48.}

\section{Carlo Lippolis}

1 Many scholars have argued that the "Parthian shot" in hunting scenes represents a moment of actual hunting. In this contribution this particular iconography is reconsidered from the point of view of the technique of representation. According to a new interpretation of the scenes in a two-dimensional space (here, in particular, a few Sasanian silver plates are considered), the so-called "Parthian shot" image "merges two parts viewed from different angles on the same space": it is a way of representation that the author calls "multi-angled shooting horseman". This visual convention, that has independent comparisons in Chinese art, was invented by Sasanian and used in central court workshops [- or 'the central court workshop'] from the early period, then it spread all over the empire in the 3th-4th centuries A.D.

\section{INDEX}

Thèmes : 3.2.3. Séleucides, Parthes et Sassanides

\section{AUTEURS}

\section{CARLO LIPPOLIS}

Università di Torino 